\title{
Analisis Beberapa Faktor yang Berpengaruh terhadap Volume Penjualan Telur Ayam Ras pada PT. Manuntung Raya, Balikpapan Utara
}

\author{
Nursida $^{1^{\star}}$, Nila Kusumawati ${ }^{2}$, dan Yanti Langi' Minanga ${ }^{3}$ \\ 1,2 Program Studi Agroteknologi, Sekolah Tinggi Pertanian Kutai Timur \\ JI. Soekarno Hatta No.1 Kab. Kutai Timur, Kalimantan Timur \\ ${ }^{3}$ Alumni Sekolah Tinggi Pertanian Kutai Tiumur \\ ${ }^{1}$ Email: nursida@stiperkutim.ac.id \\ *Penulis korespondensi: nursida@stiperkutim.ac.id
}

\begin{abstract}
PT. Manuntung Raya is a livestock company in Karang Joang Sub District, North Balikpapan. This company operate several types of livestock commodities including laying hens. Production of eggs of PT. Manuntung Raya is known as egg KM. 18. The demand off egg and market share of this company in the Balikpapan area and outside Balikpapan area. This study aims to determine the influence of the egg production, selling price, and number of buyers either simultaneously or partially to the sales volume of the eggs at PT. Manuntung Raya. This study had been done on April until Juni 2019 at PT. Manuntung Raya, North Balikpapan. The data used is times series from 2016 to 2018. Data analysis is by using descriptive statistic and multiple linear regression. The data were processed using SPSS (Statistical Package for the Social Sciens). This study results indicated that egg production, selling price, and number of buyer that simultaneously have a significant influence to sale volume of the egg sales volume at PT. Manuntung Raya on level of confidence $95 \%$ with $F$ value $>F_{\text {table }}$ value $(26.651>2.874)$. Partially egg production has a positive influence to sales volume of eggs with $\mathrm{t}$ value $\geq t$ table value (8.899> 1.960), the selling price has a negative influence to sales volume of eggs with t value $\leq t$ tabel $(-2.246>1.960)$, while the number of buyers has no influence to sales volume of eggs with $\mathrm{t}$ value $\leq t$ tabel $(-1.174<1.960)$.
\end{abstract}

Keywords: Buyers, Eggs Production, Laying Hens, Price, Sales

\begin{abstract}
ABSTRAK
PT. Manuntung Raya adalah suatu perusahaan peternakan yang berada di Kelurahan Karang Joang, Balikpapan Utara. Perusahaan ini mengusahakan beberapa jenis komoditi ternak termasuk ayam ras petelur. Produksi telur ayam ras PT. Manuntung Raya dikenal dengan telur ayam ras km.18. Telur ini diminati oleh banyak konsumen dan dipasarkan di wilayah Balikpakan maupun di luar Balikpapan. Penelitian ini bertujuan untuk mengetahui pengaruh produksi telur, harga jual, dan jumlah pembeli baik secara simultan maupun secara parsial terhadap volume penjualan telur di PT. Manuntung Raya. Penelitian ini dilaksanakan pada bulan April sampai Juni 2019 di PT. Manuntung Raya, Balikpapan Utara. Data yang digunakan adalah data runtun waktu tahun 2016-2018. Analisis data yang digunakan adalah statistik deskriptif dan regresi linear berganda. Data diolah menggunakan software SPSS. Hasil penelitian menunjukkan bahwa produksi telur, harga jual dan jumlah pembeli secara simultan berpengaruh signifikan terhadap volume penjualan telur ayam ras di PT. Manuntung Raya pada taraf kepercayaan $95 \%$ dengan nilai $F_{\text {hitung }}$ lebih besar dari nilai $\mathrm{F}_{\text {tabel }}(26,651>2,874)$. Secara parsial produksi telur berpengaruh positif terhadap volume penjualan telur ayam ras dengan nilai $t$ hitung lebih besar dari pada $t$ tabel $(8,899>1,960)$, harga jual berpengaruh negatif terhadap volume penjualan telur ayam ras dengan nilai $t$ hitung lebih besar dari nilai $t$ tabel $(-2,246>1,960)$, sementara jumlah pembeli tidak berpengaruh terhadap volume penjualan telur ayam ras dengan nilai $t$ hitung lebih kecil dari pada $t$ tabel $(-1,174<1,960)$.
\end{abstract}

Kata kunci: Ayam Ras, Harga, Pembeli, Penjualan, Produksi Telur 
http://ojs.stiperkutim.ac.id/index.php/jpt https://doi.org/10.36084/jpt..v9i2.298
Jurnal Pertanian Terpadu 9(2): 105-117, Desember 2021 ISSN 2549-7383 (online) ISSN 2354-7251 (print)

\section{Pendahuluan}

Kebutuhan pangan semakin meningkat seiring dengan tingkat pertumbuhan penduduk yang semakin tinggi. Permasalan pangan menjadi salah satu masalah yang belum sepenuhnya dapat diatasi terutama di daerah pedesaan yang tingkat ekonominya masih rendah sehingga kebutuhan pangan menjadi hal yang lebih diutamakan dibanding dengan kebutuhan yang lain (Hastuti et al., 2018). Salah satu bahan pangan yang sering dikonsumsi masyarakat adalah telur. Secara nasional, tingkat partisipasi konsumsi telur di Indonesia sebesar 73,8\% melebihi tingkat konsumsi daging dan susu yang masing-masing sebesar 38,5\% dan 31,6\% (Ariani et al., 2018). Telur merupakan salah satu bahan pangan sumber protein yang sangat berperan dalam pembentukan jaringan baru dan mengatur sistem kekebalan didalam tubuh manusia. Telur juga merupakan jenis pangan yang ketersediaannya cukup stabil serta memiliki harga yang relatif terjangkau (Lestari et al., 2015).

Salah satu komoditi peternakan yang memberikan kontribusi terbesar dalam penyediaan telur adalah telur ayam ras. Khusus di Kalimantan Timur, telur ini memberikan kontribusi sebesar $73,07 \%$ dari total produksi telur (Zaini, 2011). Selain harganya relatif murah dan mudah dijangkau, telur ayam ras juga banyak diminati karena kandungan gizinya yang baik. Telur ayam ras memiliki kandungan gizi yaitu protein $12,7 \%$, lemak 11,3\% karbohidrat 0,9\%, abu 1,0\% dan kadar air 73,7\% (Direktorat Gizi Depkes RI, 1989).

PT. Manuntung Raya adalah salah satu usaha peternakan ayam ras petelur yang telah beroperasi selama 19 tahun di km 18 Kelurahan Karang Joang, Balikpapan Utara. Perusahaan ini mengembangkan beberapa macam ternak seperi burung wallet, budidaya ikan, ayam potong, namun ayam petelur merupakan komoditi uggulannya. Populasi ayam ras petelur yang dibudidayakan di peternakan PT. Manuntung Raya saat ini adalah 60.000 ekor. Telur ayam ras yang diproduksi dikenal dengan telur ayam ras km.18. Telur ini diminati oleh banyak konsumen baik lokal maupun dari luar Kalimantan Timur. Penjualan telur ayam ras km.18 dilakukan ke beberapa tempat dan pasar di wilayah Balikpapan dan diluar Balikpapan seperti Samarinda dan Bontang bahkan pemasaran lintas pulau seperti Sulawesi.

Konsumen telur ayam ras PT. Manuntung Raya tersebar diluar wilayah Balikpapan yang menunjukkan bahwa aktivitas penjualan telur yang dilakukan oleh perusahaan bukan sekedar menjual, namun perusahaan telah melakukan kegiatan pemasaran. Meskipun wilayah pemasaran telur ayam ras PT. Manuntung Raya semakin luas, namun penjualan telur mengalami fluktuasi. Hal ini dimungkinkan karena adanya persaingan usaha yang semakin ketat. Keberlangsungan hidup suatu usaha dipengaruhi oleh kemampuan perusahaan dalam merebut pangsa pasar sehingga pelaku usaha perlu memberikan 
perhatian yang serius dalam menetapkan strategi pemasaran agar mereka mampu menembus pasar di tengah persaingan yang semakin tinggi (Wibowo et al., 2015).

Tahun 2016 hingga tahun 2018 produksi telur ayam ras PT. Manuntung Raya mengalami fluktuasi, wilayah pemasaran telur semakin luas sehingga memungkinkan jumlah pembeli semakin bertambah, namun harga telur mengalami peningkatan setiap tahun. Hal tersebut akan berpengaruh pada volume penjualan telur ayam ras pada PT. Manuntung Raya, Balikpapan Utara. Berdasarkan latar belakang, maka peneliti tertarik melakukan penelitian tentang "Analisis beberapa Faktor yang Berpengaruh Terhadap Volume Penjualan Telur Ayam Ras pada PT. Manuntung Raya, Balikpapan Utara". Tujuan penelitian adalah mengetahui pengaruh produksi telur, harga jual, jumlah pembeli terhadap volume penjualan telur baik secara simultan maupun secara parsial.

\section{Metode Penelitian}

\section{Waktu dan Tempat Penelitian}

Penelitian ini dilaksanakan pada bulan April-Juni 2019. Lokasi penelitian pada PT. Manuntung Raya, di Kelurahan Karang Joang Kecamatan Balikpapan Utara.

\section{Metode Pengumpulan Data}

Metode pengumpulan data yang digunakan adalah observasi, yaitu dengan melakukan pengamatan langsung terhadap lokasi penelitian dan wawancara langsung dengan pihak pimpinan PT. Manuntung Raya. Data primer terdisi atas data volume penjualan, produksi telur, harga jual, dan jumlah pembeli. Volume penjualan adalah banyaknya telur ayam ras yang terjual (kemasan/bulan), harga jual adalah nilai tukar telur ayam ras yang ditawarkan kepada konsumen (Rp/kemasan), produksi telur adalah banyaknya jumlah telur ayam ras yang diproduksi PT. Manuntung Raya (kemasan/bulan), dan jumlah pembeli adalah seorang pelanggan / individu, lembaga-lembaga yang membeli telur ayam ras selama 3 tahun terakhir $(2018,2017,2016)$ pada PT. Manuntung Raya (orang/bulan). Data sekunder merupakan data yang diperoleh dari referensi terkait dengan penelitian seperti jurnal dan pustaka lainnya.

\section{Metode Pengambilan Sampel}

Penelitian ini adalah studi kasus atau satu sampel saja sehingga sampel ditetapkan dengan metode dipilih berdasarkan pertimbangan bahwa pelaku usaha tersebut melakukan usahanya secara rutin dan berkelanjutan, usaha peternakan tersebut telah mandiri, memiliki surat izin usaha yang lengkap, usaha peternakan ayam ras tersebut sudah berjalan selama kurang lebih 19 tahun dan sampai sekarang masih aktif berproduksi. 
http://ojs.stiperkutim.ac.id/index.php/jpt https://doi.org/10.36084/jpt..v9i2.298
Jurnal Pertanian Terpadu 9(2): 105-117, Desember 2021 ISSN 2549-7383 (online) ISSN 2354-7251 (print)

\section{Metode Analisis Data}

\section{Analisis Statistik}

Analisis statistik dengan Regresi Linier berganda dan software SPSS yang bertujuan untuk mengetahui pengaruh variabel independent $(\mathrm{X})$ terhadap variabel dependent $(\mathrm{Y})$. Variabel independent dalam penelitian yaitu produksi telur $\left(\mathrm{X}_{1}\right)$, harga jual $\left(\mathrm{X}_{2}\right)$, dan jumlah pembeli $\left(\mathrm{X}_{3}\right)$, sedangkan variabel dependent yaitu volume Penjualan $(\mathrm{Y})$. Sebelum melakukan analisis regresi berdasarkan variabel yang akan diteliti dan terlihat bahwa ada ketidaksamaan satuan di dalam variabel tersebut, maka harus dilakukan standardize data. Menurut Solimun (2010) bila mana data yang memiliki satuan berbeda, maka satuannya dapat dihilangkan (menjadi sama) serta rentang homogen $(-3,5-+3,5)$ dengan cara transformasi menjadi data standardize.

Regresi linier berganda digunakan jika pengukuran pengaruh antara variabel melibatkan lebih dari satu variabel bebas $\left(X_{1}, X_{2}, X_{3}, \ldots, X n\right)$ (Sunyoto, 2011). Persamaan regresi linier berganda sebagai berikut:

$$
Y=a+b_{1} X_{1}+b_{2} X_{2}+b_{3} X_{3},+b n X n
$$

Keterangan: $Y=$ Volume penjualan telur ayam ras (kemasan/bulan)

a $\quad=$ Nilai konstanta

$\mathrm{X}_{1}=$ Produksi telur ayam ras (kemasan/bulan)

$\mathrm{X}_{2} \quad=$ Harga jual (Rp/kemasan)

$\mathrm{X}_{3} \quad=$ Jumlah pembeli (Orang/bulan)

$b_{1} . b_{2} \cdot b_{3}=$ nilai koefisien regresi variabel $X_{1}, X_{2}, X_{3}, \ldots, X n$.

\section{Pengujian Hipotesis}

Pengujian hipotesis yang dilakukan adalah uji $\mathrm{F}$ dan Uji $\mathrm{t}$ dengan menggunakan software SPSS (Statistical Product and Service Solutions) versi 2016. Uji F dilakukan untuk menguji apakah variabel bebas $\left(\mathrm{X}_{1}, \mathrm{X}_{2}, \mathrm{X}_{3}\right)$ secara simultan berpengaruh terhadap variabel terikat $(Y)$ dengan membandingkan antara nilai $F_{\text {tabel }}$ dan $F_{\text {hitung, apabila nilai }} F_{\text {hitung }}>F_{\text {tabel }}$ maka $\mathrm{H}_{\mathrm{a}}$ diterima, jika $\mathrm{F}_{\text {hitung }}<\mathrm{F}_{\text {tabel }}$ maka $\mathrm{H}_{\mathrm{a}}$ ditolak dengan tingkat probability yang digunakan sebesar $5 \%(\alpha=0.05)$. Uji t dilakukan untuk menguji apakah variabel bebas $\left(X_{1}\right.$, $\mathrm{X}_{2}, \mathrm{X}_{3}$,) secara parsial berpengaruh signifikan terhadap variabel terikat $(\mathrm{Y})$ dengan membandingkan antara $t_{\text {hitung }}$ dan $t_{\text {tabel, }}$ apabila nilai $t_{\text {hitung }}>t_{\text {tabel }}$ maka $\mathrm{H}_{\mathrm{a}}$ diterima yang berarti bahwa variabel $X_{1}, X_{2}$, dan $X_{3}$ dan secara parsial berpengaruh signifikan terhadap $Y$ dan jika $t_{\text {hitung }}<t_{\text {tabel }}$ maka $H_{0}$ diterima yang berarti bahwa variabel $X_{1}, X_{2}$, dan $X_{3}$ secara parsial tidak berpengaruh signifikan terhadap $Y$ dengan tingkat probability yang digunakan sebesar $5 \%$ (Nursida et al., 2020). 


\section{Hasil dan Pembahasan}

\section{Gambaran Umum dan Profil Usaha PT. Manuntung Raya}

PT. Manuntung Raya berada di KM. 18 Kelurahan Karang Joang Kecamatan Balikpapan Utara Kota Balikpapan Provinsi Kalimantan Timur. Perusahaan ini berdiri sejak tahun 2000 yang dimulai dengan budidaya ayam broiler. Sejak tahun 2010, perusahaan ini membudidayakan ayam ras petelur dan menjadikan sebagai komoditi unggulan. Sistem pemeliharaan ayam ras petelur secara intensif mulai dari fase starter yaitu dengan mempersiapkan kandang (membersihkan kandang dengan mencuci kandang, penyemprotan untuk mengurangi kutu ayam sebelumnya), dan perlengkapan kandang (tempat makan dan minum), untuk day old chiken ayam ras petelur. Jenis kandang yang digunakan adalah kandang model triple deck. Jumlah kandang sebanyak 23 kandang, setiap kandang di jaga dan dikelola maksimal 2 orang. Total karyawan yang bekerja sebanyak 48 orang dengan jabatan dan tugas yang berbeda.

\section{Deskripsi Variabel Penelitian}

1. Volume Penjualan $(\mathrm{Y})$

Capaian volume penjualan merupakan salah satu indikator keberhasilan suatu perusahaan dalam memasarkan produk (Jaya, 2015). Penjualan telur ayam ras pada PT. Manuntung Raya dalam satu kemasan sebanyak 30 butir telur. Penjualan dilakukan secara langsung di Balikpapan dan dengan sistem pesanan dari dalam dan diluar Kota Balikpapan dan Kalimantan Timur seperti Samarinda, Bontang dan Pare-Pare. Aktivitas penjualan telur yang telah dilakukan oleh PT. Manuntung Raya bukan sekedar menjual, tetapi telah melakukan proses pemasaran yang dimulai dari memahami apa yang dibutuhan oleh konsumen, melalukan riset pasar, memproduksi telur, melakukan penjualan dan promosi, menetapkan harga, serta mendistribusikan telur dengan baik ke konsumen serta menciptakan kepuasan yang akhirnya membentuk loyalitas konsumen. Perkembangan volume penjualan telur ayam ras periode Januari 2016-Desember 2018 dapat dilihat pada Gambar 1.

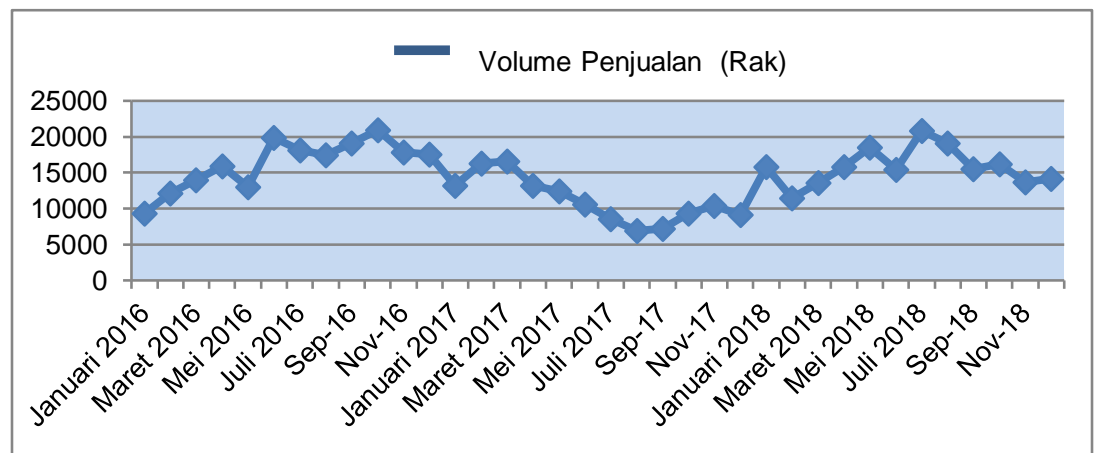

Gambar 1. Perkembangan volume penjualan telur ayam ras pada PT. Manuntung Raya 
Gambar 1 menunjukkan bahwa volume penjualan telur periode 2016-2018 mengalami fluktuasi dan cenderung mengalami peningkatan sehingga omset penjualan telur juga akan meningkat. Besarnya penjualan akan berpengaruh terhadap volume penjualan produk, begitu sebaliknya apabila penjualan tidak mencapai target optimal volume penjualan juga akan menurun. Santi et al., (2019) bahwa volume penjualan berpengaruh terhadap pendapatan. Peningkatan volume penjualan telur ayam ras pada PT. Manuntung Raya pada 3 tahun terakhir ini tidak terlepas dari kemampuan perusahaan dalam meningkatkan kegiatan pemasaran seperti memahami keinginan konsumen baik kuantitas maupun kualitas telur. Jaya (2015), bahwa pemasaran dimulai dari kegiatan mengidentifikasi apa yang diinginkan dan dibutuhkan oleh konsumen sasarannya, kemudian menemukan cara memuaskan konsumen melalui proses pertukaran dengan tetap berpedoman pada tujuan dan keinginan perusahaan.

2. Jumlah Produksi $\left(\mathrm{X}_{1}\right)$

Perkembangan produksi telur ayam ras pada PT. Manuntung Raya periode Januari 2016 - Januari 2018 dapat dilihat pada Gambar 2.

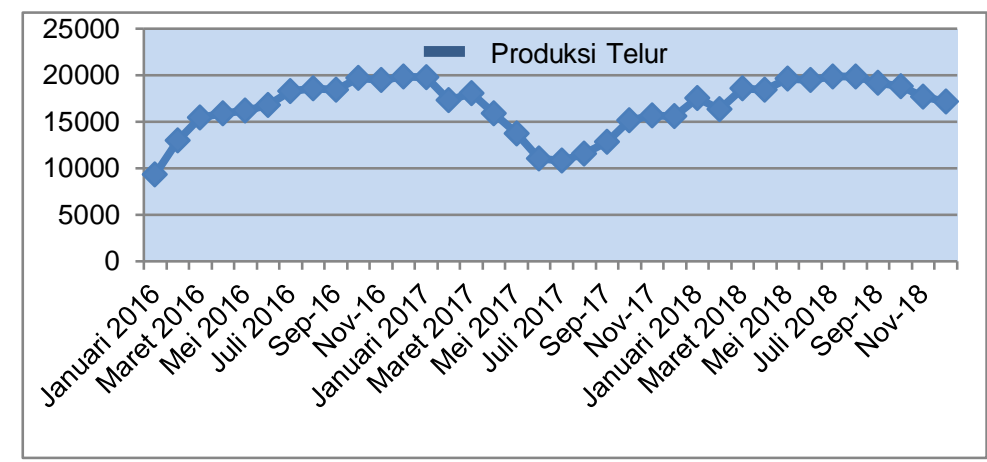

Gambar 2. Perkembangan produksi telur ayam ras pada PT. Manuntung Raya

Gambar 2 menunjukkan bahwa produksi telur ayam ras pada PT. Manuntung Raya dari bulan Januari 2016 sampai dengan Desember 2018 mengalami fluktuasi. Hal ini disebabkan karena populasi ayam dipelihara dan bertelur mengalami penurunan pada tahun 2017. Tegar (2014), bahwa faktor-faktor yang mempengaruhi produksi telur adalah pemeliharaan, genetik, suhu lingkungan, pencahayaan, kepadatan kandang. Selain itu penurunan produksi telur juga disebabkan tatalaksana pemeliharaan seperti pemberian pakan dan minum. Tumion et al., (2017), bahwa kualitas dan kuantitas pakan yang diberikan ke ayam disesuaikan dengan kebutuhan berdasarkan umur dan tatalaksana pemeliharannya sehingga produksi dan kualitas telur akan maksimal. Pakan merupakan asupan nutrisi, apabila pemberian pakan tidak sesuai dengan standar akan berpengaruh terhadap penyerapan nutrisi ayam berkurang dan tentunya akan mengakibatkan turunnya produksi telur. Hal ini juga didukung oleh pernyataan Hastuti et al., (2018), bahwa umur ayam ras petelur mempengaruhi jumlah pemberian pakan. 


\section{Harga Jual $\left(\mathrm{X}_{2}\right)$}

Penetapan harga jual telur ayam ras pada PT. Manuntung Raya didasarkan pada harga yang berlaku di pasaran, namun cenderung tetap dalam waktu satu tahun. Perkembangan harga jual telur ayam ras dapat dilihat pada Gambar 3.

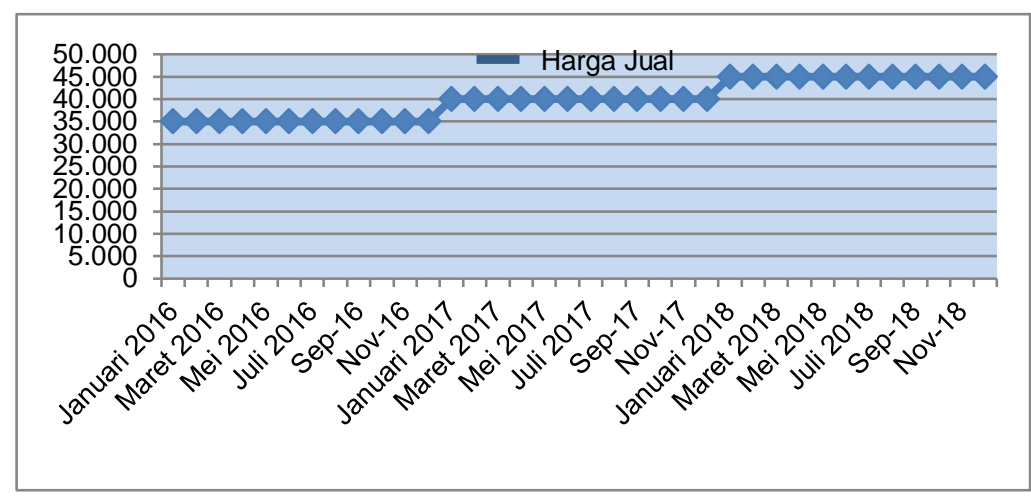

Gambar 3. Perkembangan harga jual telur ayam ras pada PT. Manuntung Raya

Gambar 3 menunjukkan bahwa harga jual telur ayam ras pada PT. Manuntung Raya, sejak tahun 2016 sampai dengan tahun 2018 mengalami kenaikan harga rata-rata sebesar Rp. 5.000 setiap 30 butir per tahun. Hartanti (2016), bahwa seiring pergantian tahun harga barang mentah melonjak naik, maka biaya produksi pun semakin naik seiring dengan bertambah mahalnya barang-barang material yang diolah dan hal ini akan mempengaruhi penjualan yang dilakukan. Harga yang digunakan dalam penelitian adalah harga rata-rata dalam setiap bulannya, sehingga perubahannya tidak signifikan dan cenderung stabil. Perubahan harga telur ayam ras pada PT. Manuntung Raya saat menjelang bulan puasa, natal dan tahun baru serta adanya kenaikan biaya produksi yang tentu berpengaruh terhadap tingkat produksi. Hal ini sesuai dengan pernyataan Susilowati (2016) bahwa kenaikan beban tenaga kerja langsung dan harga berbagai bahan baku mempengaruhi kenaikan harga. Fuadi et al., (2017), bahwa tingkat produksi, kualitas, penanganan pascapanen, dan saluran ditribusi pemasaran mempengaruhi harga jual. Harga jual ayam telur ayam juga di dasarkan pada harga pasar. Menurut Beutari \& Laelisneni (2017), bahwa pesaing, konsumen dan pasar tidak dapat dianalisa sehingga penetapan harga jual didasarkan pada harga yang ada di pasar atau dikenal dengan metode going rate pricing.

\section{Jumlah Pembeli $\left(X_{3}\right)$}

Pembeli adalah orang atau pihak yang dilayani kebutuhannya. Pembeli yang dimaksudkan pada PT. Manuntung Raya adalah orang atau badan yang langsung membeli produk telur ayam ras pada perusahaan ini, baik yang berupa konsumen akhir maupun berupa agen (pedagang sementara) yang melebihi dua kali pembelian dalam satu bulan atau pembelian produk telur ayam ras secara rutin setiap bulannya dalam jumlah yang 
banyak. Perkembangan jumlah pembeli telur ayam ras selama bulan Januari 2016 sampai Desember 2018 dapat dilihat pada Gambar 4.

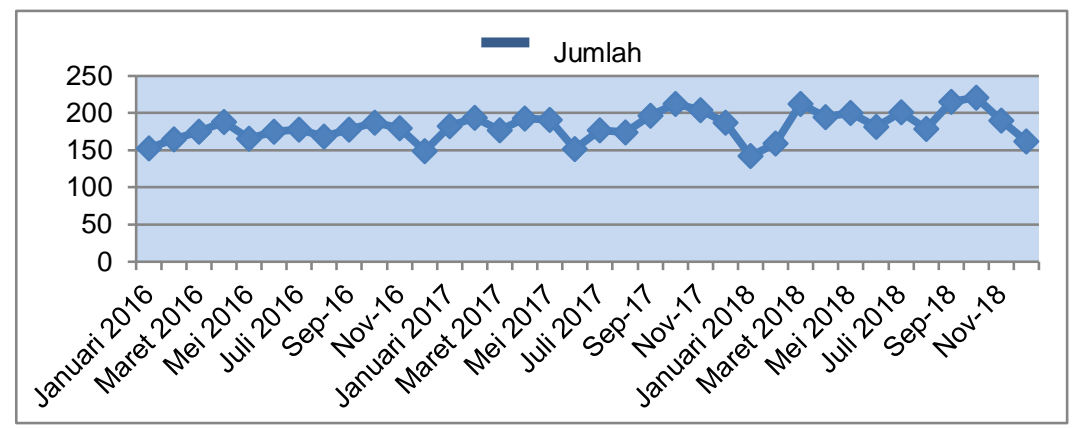

Gambar 4. Perkembangan jumlah pembeli telur ayam ras pada PT. Manuntung Raya

Gambar 4 menunjukkan terlihat bahwa jumlah pembeli telur ayam ras pada PT. Manuntung Raya dari bulan Januari 2016 samapai bulan Desember 2018 cenderung mengalami fluktuasi yang cenderung mengalami peningkatan. Perubahan jumlah pembeli tidak terlepas dari kinerja perusahaan untuk menjaga dan mempertahankan pembeli serta kepercayaan para pelanggan terhadap kualitas telur ayam ras pada PT. Manuntung Raya. Miauw (2016) bahwa sikap konsumen berpengaruh signifikan secara parsial atau individual terhadap keputusan pembelian konsumen. Konsumen akan memperhatikan kualitas produk yang akan dibelinya karena berkaitan dengan kepuasan.

\section{Faktor-Faktor yang Mempengaruhi Volume Penjualan Telur Ayam Ras}

Variabel penelitian yang digunakan yaitu variabel bebas (Independent variable) terdiri dari jumlah produksi $\left(X_{1}\right)$, harga jual $\left(X_{2}\right)$, jumlah pembeli $\left(X_{3}\right)$, sedangkan untuk variabel terikat (Dependent Variable) yaitu volume penjualan telur ayam ras (Y). Hasil analisis regresi linier berganda diperoleh nilai pada tabel 1.

Tabel 1. Hasil analisis regresi linier berganda beberapa faktor yang berpengaruh terhadap volume penjualan telur ayam ras

\begin{tabular}{llccccc}
\hline Variabel Bebas & Koefisien Regresi & Std. Error & $\mathbf{t}_{\text {hit }}$ & Prob & $\mathbf{R}$ & $\mathbf{r}^{2}$ \\
\hline Jumlah Produksi $\left(\mathrm{X}_{1}\right)$ & 0.890 & 0.100 & 8.899 & 0.000 & 0.844 & 0.712 \\
Harga jual $\left(\mathrm{X}_{2}\right)$ & -0.230 & 0.103 & -2.246 & 0.032 & -0.369 & 0.136 \\
Jumlah pembeli $\left(\mathrm{X}_{3}\right)$ & -0.121 & 0.103 & -1.174 & 0.249 & -0.203 & 0.041 \\
\hline Constanta $=1.000 \mathrm{E}-013$ & & & & & & \\
$\mathrm{R}$ Square $\quad=0.714$ & & & & & \\
$\mathrm{~F}_{\text {hitung }}=26.651$ & & & & & & \\
$\mathrm{~F}_{\text {tabel }}=2,874$ & & & & & & \\
$\mathrm{t}$ tabel $\quad=1.960$ & & & & & &
\end{tabular}

Berdasarkan hasil analisis dan perhitungan seperti yang terlihat pada tabel 4 maka dapat dibuat persamaan sebagai berikut:

$$
Y=1.000 E-013+0.890 X_{1}+-0.230 X_{2}+-0.121 X_{3}+0.559 e
$$

Persamaan diatas menjelaskan bahwa konstanta dari sebesar 1.000E-013. Nilai tersebut menunjukkan bahwa jika jumlah produksi telur ayam ras $\left(X_{1}\right)$, harga jual $\left(X_{2}\right)$, dan jumlah pembeli $\left(X_{3}\right)=0$, maka volume penjualan telur ayam ras $(Y)$ sebesar 1.000E-013. 
Koefisien regresi $X_{1}$ adalah 0,890 yang berarti bahwa jika produksi telur ayam ras naik sebesar 1 kemasan (30 butir), maka volume penjualan telur ayam ras pada PT. Manuntung Raya akan meningkat sebesar 0,890 kemasan, koefisien regresi $X_{2}$ adalah -0,230 yang berarti bahwa jika harga jual telur ayam ras naik sebesar $\mathrm{Rp} 1$, maka volume penjualan telur ayam ras menurun sebesar 0,23 kemasan, sedangkan koefisien regresi $X_{3}$ adalah 0,121 yang berarti bahwa jika jumlah pembeli telur ayam ras naik sebesar 1 , maka volume penjualan telur ayam ras menurun sebesar 0,121 kemasan.

\section{Pengaruh Variabel Produksi Telur $\left(X_{1}\right)$, Harga Jual $\left(X_{2}\right)$, dan Jumlah Pembeli $\left(X_{3}\right)$ secara Simultan terhadap Volume Penjualan Telur Ayam Ras (Y)}

Hasil perhitungan diperoleh nilai $F_{\text {hitung }}$ sebesar 26,651 . Nilai tersebut menunjukkan bahwa $F$ hitung lebih besar dari nilai $F_{\text {tabel }}$ yaitu 2,874 $(26,651>2,874)$. Hal ini berarti bahwa produksi telur $\left(X_{1}\right)$, harga jual $\left(X_{2}\right)$, dan jumlah pembeli $\left(X_{3}\right)$ secara simultan berpengaruh signifikan terhadap volume penjualan telur $(Y)$. Selanjutnya mengetahui kuatnya hubungan variabel produksi telur ayam ras $\left(X_{1}\right)$, harga jual $\left(X_{2}\right)$, dan jumlah pembeli $\left(X_{3}\right)$ secara simultan terhadap volume penjualan telur $(Y)$ dapat dilihat dari nilai koefisien korelasi berganda $(r)$ yaitu sebesar 0.845 ini berarti bahwa variabel produksi telur ayam ras $\left(X_{1}\right)$, harga jual $\left(\mathrm{X}_{2}\right)$, dan jumlah pembeli $\left(\mathrm{X}_{3}\right)$ secara simultan memiliki hubungan yang kuat dan positif terhadap volume penjualan telur ayam ras $(Y)$, sementara nilai koefisien determinan $\left(R^{2}\right)$ sebesar 0,714 . Hal ini berarti besarnya sumbangan variabel bebas terhadap variasi naik turunnya volume penjualan telur ayam ras sebesar $71,4 \%$ sementara sisanya $28,6 \%$ dipengaruhi oleh faktor lain diluar variabel yang diteliti.

Pengaruh Variabel Jumlah Produksi, Harga Jual, dan Jumlah Pembeli secara sendirisendiri (parsial) terhadap Volume Penjualan Telur Ayam Ras pada PT. Manuntung Raya, Balikpapan Utara

Pengujian pengaruh variabel secara parsial dilakukan dengan mengunakan Uji t.

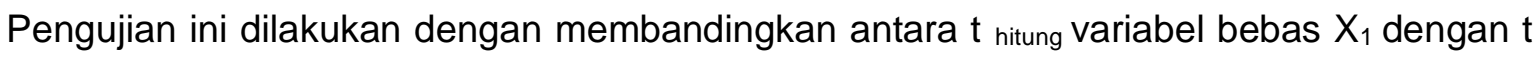
tabel pada taraf kepercayaan $95 \%$ atau $\alpha=0.05$.

Tabel 2. Hasil pengujian variabel bebas secara parsial

\begin{tabular}{lcc}
\hline Variabel Bebas & Uji t & Keterangan \\
\hline Jumlah Produksi $\left(\mathrm{X}_{1}\right)$ & $8.899>1.960$ & Berpengaruh positif \\
Harga jual $\left(\mathrm{X}_{2}\right)$ & $-2.246>1.960$ & Berpengaruh negatif \\
Jumlah pembeli $\left(\mathrm{X}_{3}\right)$ & $-1.174<1.960$ & Tidak berpengaruh \\
\hline
\end{tabular}

Sumber: Data Hasil Olahan (2019).

1. Pengaruh Jumlah Produksi telur $\left(X_{1}\right)$ terhadap Volume Penjualan Telur Ayam Ras

Produksi telur Ayam ras merupakan banyaknya jumlah produksi yang diproduksi dalam satu bulan ditambah dengan jumlah produk yang bulan sebelumnya terjual yang ditawarkan kepada konsumen. Hasil analisis diperoleh nilai $t$ hitung variabel produksi telur ayam ras $\left(X_{1}\right)$ sebesar 8,899 sedangkan nilai $t_{\text {tabel }} 1,960$. Hal ini menunjukkan bahwa nilai $t_{\text {hitung }}$ lebih besar dari pada $t_{\text {tabel }}(8,899>1,960)$ maka berarti variabel produksi telur ayam 
ras $\left(X_{1}\right)$ secara parsial berpengaruh signifikan terhadap volume penjualan telur ayam ras $(\mathrm{Y})$, artinya bahwa jika produksi telur ayam ras naik maka volume penjualan juga mengalami kenaikan. Kenaikan produksi mendorong perusahaan untuk meningkatkan aktivitas pemasaran, seperti memperluas wilayah pemasaran, menjaga dan memberi kepercayaan kepada pelanggan yang loyal terhadap produk dan perusahaan sehingga berdampak positif pada pendapatan perusahaan. Hasil penjualan sangatlah berpengaruh terhadap keuangan perusahaan, semakin hasil nya meningkat semakin besar kemungkinan laba yang diperoleh apabila perusahaan tersebut dapat menstabilkan biaya produksi (Hartanti, 2016). Nilai koefisien korelasi parsial ( $r$ ) variabel produksi telur ayam ras $\left(\mathrm{X}_{1}\right)$ terhadap variabel volume penjualan $(\mathrm{Y})$ sebesar 0,844 hal ini menunjukkan bahwa hubungan variabel produksi telur ayam ras $\left(X_{1}\right)$ terhadap volume penjualan telur ayam ras (Y) kuat dan positif.

2. Pengaruh Harga Jual $\left(X_{2}\right)$ terhadap Volume Penjualan Telur Ayam Ras

Harga jual merupakan nilai tukar telur ayam ras yang ditawarkan oleh PT. Manuntung Raya kepada konsumen. Kesepakatan jual-beli antara produsen dan konsumen ditentukan oleh harga. Sebelum barang tersebut beredar di pasar, penetapan harga sebelumnya telah disepakati karena harga sendiri memperlihatkan nilai ekonomis dari suatu produk (Utami, 2020). Untuk memperoleh pendapatan dan labah bersih perusahaan, maka penetapan harga jual merupakan faktor penting yang harus diperhatikan (Crisdandi, 2015).

Hasil analisi diperoleh nilai $t$ hitung variabel harga jual telur ayam ras $\left(X_{2}\right)$ sebesar 2,246 sedangkan nilai $t$ tabel sebesar 1,960 hal ini menunjukkan bahwa nilai $t$ hitung lebih besar dari nilai $t$ tabel $(-2,246>1,960)$ maka berarti variabel harga jual telur ayam ras $\left(X_{2}\right)$ secara parsial berpengaruh negatif terhadap volume penjualan telur ayam ras pada PT. Manuntung Raya, yang artinya bahwa jika harga jual telur ayam ras naik, maka volume penjualan akan menurun. Hal ini sesaui dengan pendapat Susilowati (2016), bahwa ketika harga barang naik, maka jumlah yang diminta mengalami penurunan, dan jika harga barang turun, jumlah yang diminta naik.

Nilai koefisien korelasi parsial $(r)$ variabel harga jual telur ayam ras $\left(X_{2}\right)$ terhadap variabel volume penjualan $(Y)$ sebesar $-0,369$. Hal ini menunjukkan bahwa hubungan variabel harga jual telur ayam ras $\left(\mathrm{X}_{2}\right)$ terhadap volume penjualan telur ayam ras $(\mathrm{Y})$ kuat dan negatif atau mempunyai hubungan linear sempurna tidak langsung/korelasi karena nilai mendekati -1 dimana $-1 \leq r<+1$ yang menyatakan adanya hubungan linear sempurna secara tidak langsung /korelasi negatif. 
3. Pengaruh Jumlah Pembeli $\left(X_{3}\right)$ terhadap Volume Penjualan Telur Ayam Ras

Jumlah pembeli merupakan banyaknya orang yang langsung membeli atau memesan telur ayam ras pada PT. Manuntung Raya lebih dari dua kali pembelian produk dalam setiap bulan baik yang konsumen akhir maupun yang berupa agen atau pedagang

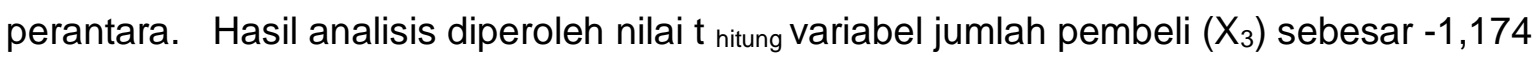
sedangkan nilai $t_{\text {tabel }}$ sebesar 1,960 hal ini menunjukkan bahwa nilai $t$ hitung yang diperoleh lebih kecil dari pada $t_{\text {tabel }}(-1,174<1,960)$ maka berarti variabel jumlah pembeli telur ayam ras $\left(X_{3}\right)$ secara parsial tidak berpengaruh terhadap volume penjualan telur ayam ras pada PT. Manuntung Raya, yang artinya bahwa volume penjualan telur ayam ras tidak dipengaruhi oleh jumlah pembeli. Hal ini tidak sesuai dengan pendapat Pakpahan (2009), semakin banyak jumlah pelanggan suatu perusahaan akan semakin dikenal oleh masyarakat luas dan mendorong naiknya angka penjualan yang akan berdampak pada peningkatan volume penjualan. Jumlah pembeli atau konsumen telur ayam ras PT. Manuntung Raya terdiri dari pelanggan tetap dan pelanggan tidak tetap. Jumlah pembelian telur oleh setiap pelanggan tidak tetap tergantung kebutuhan pelanggan. Pelanggan yang membeli dalam jumlah yang banyak adalah pelanggan tetap dengan tujuan untuk di jual kembali, sedangkan pelanggan tidak tetap membeli dalam jumlah yang sedikit. Nilai koefisien korelasi parsial $(r)$ variabel jumlah pembeli $\left(X_{3}\right)$ terhadap variabel volume penjualan $(Y)$ sebesar $-0,203$ hal ini menunjukkan bahwa hubungan variabel jumlah pembeli $\left(\mathrm{X}_{3}\right)$ terhadap volume penjualan telur ayam ras $(\mathrm{Y})$ lemah dan negatif.

\section{Kesimpulan}

Berdasarkan hasil dan pembahasan yang telah dilakukan maka dapat ditarik kesimpulan bahwa produksi telur ayam ras $\left(X_{1}\right)$ berpengaruh positif terhadap volume penjualan telur ayam ras $(Y)$ di PT. Manuntung Raya, dengan nilai $t$ hitung lebih besar dari pada $t_{\text {tabel }}(8,899>1,960)$. Harga jual $\left(x_{2}\right)$ berpengaruh negatif terhadap volume penjualan telur ayam ras $(Y)$, dengan nilai $t$ hitung lebih besar dari nilai $t$ tabel $(-2,246>1,960)$. Jumlah pelanggan $\left(\mathrm{X}_{3}\right)$ tidak berpengaruh terhadap volume penjualan telur ayam ras $(\mathrm{Y})$ dengan nilai thitung lebih kecil dari pada $t_{\text {tabel }}(-1,174<1,960)$. Pengaruh produksi telur $\left(X_{1}\right)$, harga jual $\left(X_{2}\right)$, dan jumlah pembeli $\left(X_{3}\right)$ secara simultan berpengaruh nyata terhadap volume

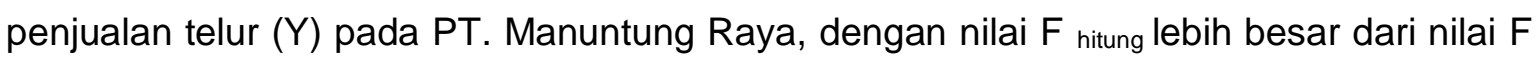
tabel $(26,651>2,874)$. Berdasarkan hasil penelitian dapat disarankan bahwa PT. Manuntung Raya tetap mempertahankan produksi telur ayam ras, menjaga agar harga telur tetap stabil dan mempertahankan loyalitas pelanggan terutama pelanggan tetap mengingat ketiga faktor tersebut berpengaruh signifikan terhadap volume penjualan telur. 


\section{Daftar Pustaka}

Ariani, M., Suryana, A., Suhartini, S. H., \& Saliem, H. P. (2018). Keragaan Konsumsi Pangan Hewani Berdasarkan Wilayah dan Pendapatan di Tingkat Rumah Tangga. Analisis Kebijakan Pertanian, 16(2), 147-163. https://doi.org/10.21082/akp.v16n2.2018

Beutari, D. R., \& Laelisneni. (2017). Analisis Penetapan Harga Jual Dalam Perencanaan Laba Pada Home Industri Tempe Setia Budi Medan. Jurnal Bisnis Administrasi, 06(01), 52-60.

Crisdandi, P. (2015). Pengaruh Biaya Pemeliharaan dan Harga Jual Terhadap Pendapatan Petani Cengkeh Di Desa Tirta Sari Pada Tahun 2014. Jurnal Jurusan Pendidikan Ekonomi (JJPE), 5(1), 1-11.

Direktorat Gizi Depkes RI. (1989). Daftar Komposisi Bahan Makanan. Jakarta: Bharata.

Fuadi, A., Susanti, E., \& Kasimin, S. (2017). Analisis Faktor - Faktor Yang Mempengaruhi Harga Jual Kedelai Tingkat Petani Pada Sentral Produksi Di Kecamatan Peudada Kabupaten Bireuen. Jurnal IImiah Mahasiswa Pertanian Unsyiah, 2(2), 138-146.

Hartanti. (2016). Pengaruh Biaya Produksi Terhadap Penjualan Pada PT. Shindengen Indonesia. Moneter, 3(1), 83-99.

Hastuti, D., Prabowo, R., \& Syihabudin, A. A. (2018). Tingkat Hen Day Production (HDP) dan Break Event Point (BEP) Usaha Ayam Ras Petelur (Gallus sp). Agrifo: Jurnal Agribisnis Universitas Malikussaleh, 3(2), 64. https://doi.org/10.29103/ag.v3i2.1111

Jaya, P. A. S. (2015). Pengaruh Biaya Peromosi dan Harga Jual Terhadap Volume Penjualan Dupa Pada Putra Mas di Desa Bulian. Jurnal Jurusan Pendidikan Ekonomi (JJPE), 5(1), 1-8.

Lestari, A. M., Hudoyo, A., \& Kasymir, E. (2015). Proyeksi Produksi dan Konsumsi Telur Ayam Ras di Provinsi Lampung. JillA, 3(3), 287-293.

Miauw, K. Y. H. (2016). Motivasi Konsumen Dan Sikap Konsumen Terhadap Keputusan Pembelian Di Wild. PERFORMA: Jurnal Manajemen Dan Start-Up Bisnis, 1(5), 567575.

Nursida, Abdillah, A. H., \& Timang, A. (2020). Analisis Beberapa Faktor Yang Berpengaruh Terhadap Pendapatan Peternak Babi di Kecamatan Sangatta Utara. Jurnal Pengembangan Penyuluhan Pertanian, 17(32), 184-195.

Pakpahan. (2009). Pengaruh Rasio Profitabilitas, Rasio Solvabilitas, dan Resiko Sistematis terhadap Harga Saham Properti Di Bursa Efek. Jakarta.

Santi, N. W. A., Haris, I. A., \& Sujana, I. N. (2019). Pengaruh Harga Jual dan Volume Penjualan Terhadap Pendapatan UD. Broiler Putra di Dusun Batumulapan Kabupaten Klungkung Pada Tahun 2015-2017. Jurnal Pendidikan Ekonomi, 11(1), 116-127. https://doi.org/10.23887/jjpe.v11i1.20090

Solimun. (2010). Analisis Multivariat Pemodelan Struktural Metode Partial Least Square Pls. Malang: Citra, Malang.

Sunyoto, D. (2011). Analisis Regresi dan Uji Hipotesis. Yogyakarta: Center for Academic Publishing Service. 
Susilowati. (2016). Analisis Faktor-Faktor Yang Mempengaruhi Volume Penjualan Feminime Hygine Sirih PT. Romos Inti Kosmetik Surabaya. JURNAL LENTERA: Kajian Keagamaan, Keilmuan Dan Teknologi, 14(2), 243-264.

Tegar, M. (2014). Faktor-Faktor Yang Mempengaruhi Produksi Telur dan Kualitas Telur. Program Studi Peternakan. Universitas Udayana.

Tumion, B., Panelewen, V. V. ., Makalew, A., \& Rorimpandey, B. (2017). Pengaruh Pakan dan Tenga Kerja Terhadap Keuntungan Usaha Ayam Ras Petelur Vony Kanaga di Kelurahan Tawaan Kota Bitung (Studi Kasus). Zootec, 37(2), 207-215. https://doi.org/10.35792/zot.37.2.2017.15800

Utami, N. W. (2020). Penetapan Harga, Tujuan, Metode dan Strategi. Retrieved from Jurnal Entrepreneur website: https://www.jurnal.id/id/blog/pengertian-penetapan-hargatujuan-metode-dan-strategi/

Wibowo, D. H., Arifin, Z., \& Sunarti. (2015). Analisis Strategi Pemasaran Untuk Meningkatkan Daya Saing UMKM (Studi pada Batik Diajeng Solo). Jurnal Administrasi Bisnis (JAB), 29(1), 59-66.

Zaini, A. (2011). Analisis Prospek Pemasaran Ayam Petelur di Kalimantan Timur. EPP, $8(1), 1-8$. 